\title{
Phytomedicine
}

Phytomedicine 15 (2008) 710-721

www.elsevier.de/phymed

\section{Protective effects of Angelica sinensis extract on amyloid $\beta$-peptide-induced neurotoxicity}

\author{
Shih-Hao Huang ${ }^{\mathrm{a}, \mathrm{c}}$, Chun-Mao Lin ${ }^{\mathrm{b}}$, Been-Huang Chiang ${ }^{\mathrm{a}, *}$ \\ ${ }^{a}$ Institute of Food Science and Technology, National Taiwan University, Taipei, Taiwan \\ ${ }^{\mathrm{b}}$ College of Medicine, Taipei Medical University, Taipei, Taiwan \\ ${ }^{\mathrm{c}}$ Department of Food Science, Taipei College of Marinetime Technology, Taipei, Taiwan
}

\begin{abstract}
The protective effects of alcohol extract from the root of Angelica sinensis (AS) on $\beta$-amyloid peptide (A $\beta$ )-induced toxicity and the mechanism of these effects were investigated. $\mathrm{A} \beta$ is a pathological hallmark of Alzheimer's disease; it decreased viability of Neuro $2 \mathrm{~A}$ cells in a concentration-dependent manner with $\mathrm{IC}_{50}$ of $14.9 \mu \mathrm{M}$. AS extract resulted in dose-dependent anti-A $\beta$ toxicity according to MTT assay. Reactive oxygen species (ROS) analysis revealed a significant production of hydrogen peroxide, decreased glutathione (GSH) levels and increased lipid peroxidation (TBARS value) in the $\mathrm{A} \beta$-treated Neuro $2 \mathrm{~A}$ cells. The $\mathrm{A} \beta$-treated cells also showed a significant decline in the mitochondrial transmembrane potential $(\Delta \Psi \mathrm{m})$ and increase in the mitochondrial volume, and portions of the cytoplasm were sequestered by a membrane-bound vacuole. The malfunctions of Neuro $2 \mathrm{~A}$ cells caused by $\mathrm{A} \beta$ were attenuated using AS extract. The AS extract protected cell viability against $\mathrm{A} \beta$-induced oxidative damage (ROS, TBARS, and GSH contents) and rescued the $\Delta \Psi \mathrm{m}$ levels in a dose-dependent manner: the dosages of 25, 50, 100, and $200 \mu \mathrm{g} / \mathrm{ml}$ recovered $77 \%, 87 \%, 102 \%$, and $105 \%$ of $\Delta \Psi \mathrm{m}$, respectively. AS extract also recovered the enlarged mitochondria mass with dosages from 25 to $200 \mu \mathrm{g} / \mathrm{ml}$. The results of this study demonstrated that AS extract possessed the activity to prevent the neurotoxicity induced by $\mathrm{A} \beta$-associated oxidative stress, implying that AS has a potential role in the prevention of Alzheimer's diseases.
\end{abstract}

(C) 2008 Elsevier GmbH. All rights reserved.

Keywords: Angelica sinensis; $\beta$-Amyloid peptide; Glutathione; Mitochondria; Mitochondrial transmembrane potential ( $\Delta \Psi \mathrm{m})$; ROS

\section{Introduction}

The rhizome of Angelica sinensis (AS) (Oliv.) Diels (Umbelliferae), known as Dong-gui in Chinese, is one of the most important traditional Chinese medicines. AS is frequently used in prescriptions for treatment of psychosomatic illness, amnesia, anemia, and gynecological diseases. It also serves as a sedative or a tonic agent

\footnotetext{
${ }^{*}$ Corresponding author. Tel.: + 886233664119 ; fax: +886223620849

E-mail address: bhchiang@ntu.edu.tw (B.-H. Chiang).
}

(Hsu and Peacher, 1976). The active components of AS include ligustilide and phthalides, which are the main components of its volatile essential oil. Ferulic acid (FA) and polysaccharides are found in the non-aromatic fractions.

$\beta$-Amyloid peptide $(\mathrm{A} \beta)$ is a major component of the senile plaques which are a pathological hallmark of Alzheimer's disease (AD) (Yankner, 1996; Varadarajan et al., 2000; Butterfield and Kanski, 2001). The truncated $\mathrm{A} \beta$ fragments $\mathrm{A} \beta_{1-40}, \mathrm{~A} \beta_{1-42}$ or $\mathrm{A} \beta_{25-35}$ exhibit toxicity to neurons, both in vitro and in vivo (Varadarajan et al., 2000). A $\beta$-induced cytotoxicity is 
caused by the intracellular accumulation of $\mathrm{H}_{2} \mathrm{O}_{2}$, leading to the peroxidation of membrane lipids and finally to cell death (Lyras et al., 1997). The generation of reactive oxygen species (ROS) and oxidative damage are believed to be involved in the pathogenesis of neurodegenerative disorders. Recent evidence indicates that oxidative stress occurs early in the progression of $\mathrm{AD}$, long before the development of senile plaques. The interaction of abnormal mitochondria, redox transition metals, and oxidative stress response elements contributes to the generation of ROS in diseased neurons (Zhu et al., 2003). Several agents, including antioxidants and free radical scavengers, have been shown to be neuroprotective both in vitro and in vivo against $\mathrm{A} \beta$-induced toxicity (Heo et al., 2004; Wang et al., 2001).

FA (4-hydroxy-3-methoxycinnamic acid), the major phenolic compound in AS, has antioxidant and antiinflammatory activities with a chemopreventive effect on carcinogenesis (Lu et al., 2005; Ou and Kwok, 2004). The activities of AS are often linked to its FA content. FA has been demonstrated to protect against free radicalmediated changes in conformation with synaptosomal membrane proteins (Kanski et al., 2002). Long-term oral administration of FA significantly reduced $\mathrm{A} \beta_{1-42^{-}}$ induced memory impairment in mice (Yan et al., 2001).

Since AS is a potential medicine for prevention of ROS-associated diseases, in the current studies we investigated the protective effects of ethanol extract of AS (AS extract) on Neuro 2A cells exposed to amyloid peptide $\mathrm{A} \beta_{25-35}$. The active components of AS extract were analyzed, and the possible mechanism of the protective effect of AS extract against $\mathrm{A} \beta_{25-35}$-induced neurotoxicity of Neuro 2A cells was investigated in order to explore the potential medicinal uses of AS in the prevention of $\mathrm{AD}$.

\section{Materials and methods}

\section{Chemicals and reagents}

$\mathrm{A} \beta_{25-35}$ was from Digital Gene Biosciences (Taipei, Taiwan). The $2^{\prime}, 7^{\prime}$-dichlorodihydrofluorescein diacetate (DCF-DA), Chloromethylfluorescein-diacetate (CMFDA), Nonyl Acridine Orange (NAO), and rhodamine 123 (Rh123) were purchased from Molecular Probes, Inc. (Eugene, OR). Other chemicals were purchased from Sigma (St. Louis, MO). Solvents were from E. Merck (Darmstadt, Germany). Minimum essential medium (MEM), fetal bovine serum (FBS), penicillin, and streptomycin were obtained from Gibco BRL (Grand Island, NY).

\section{Preparation of AS extract}

The smoke-dried AS, purchased from a Chinese medicine store in Taipei, was identified by the Center of Herbal Authentication of Taipei Medical University and stored at $-20{ }^{\circ} \mathrm{C}$. After slicing, $40 \mathrm{~g}$ of AS was extracted by 21 of boiling ethanol solution $(20 \%)$ for $15 \mathrm{~min}$, mimicking the AS tonic preparation. The infusion was filtered to remove insoluble materials, concentrated by rotary evaporator, and freeze dried. The dried extract was stored at $-70{ }^{\circ} \mathrm{C}$ and was used in all experiments.

\section{Determination of phenolic compounds of AS extract}

The phenolic acids were analyzed by HPLC (Agilent 1100 HPLC system, Palo Alto, CA) equipped with a diode-array detector (DAD). The separations were performed on a HS ODS column $(5 \mu \mathrm{m}, 250 \times 4.6 \mathrm{~mm}$, Torrance, CA) at $25^{\circ} \mathrm{C}$. Aliquots of $20-\mu 1$ were injected and eluted at a flow rate $0.8 \mathrm{ml} / \mathrm{min}$, with a mobile phase composed of solution A $(30 \mathrm{mM}$ potassium dihydrogen phosphate, $\mathrm{pH}$ 3.5) and solution B (acetonitrile/ $\mathrm{H}_{2} \mathrm{O}=80 / 20$ ). Phenolic compounds in the AS extract were eluted with gradient from $100 \%$ A initially to $90 \%$ $\mathrm{A}$ and $10 \% \mathrm{~B}$ at $20 \mathrm{~min}, 88 \% \mathrm{~A}$ and $12 \% \mathrm{~B}$ at $30 \mathrm{~min}$, $70 \% \mathrm{~A}$ and $30 \% \mathrm{~B}$ at $35 \mathrm{~min}, 40 \% \mathrm{~A}$ and $60 \% \mathrm{~B}$ at $45 \mathrm{~min}$, and $100 \% \mathrm{~B}$ at $50 \mathrm{~min}$. Detection was done at $320 \mathrm{~nm}$ for FA and $210 \mathrm{~nm}$ for other phenolic acids. The concentrations of phenolic acids in the samples were calculated according to the standard curve. The results were expressed as milligrams per gram of AS extract.

\section{Cell culture}

Neuro 2A neuroblastoma cells (BCRC 60026) were purchased from CCRC (Culture Collection and Research Center, Hsinchu, Taiwan). Cells were grown in MEM containing 10\% FBS, $1 \%$ non-essential amino acid and $100 \mu \mathrm{g} / \mathrm{ml}$ penicillin-streptomycin. Conditions were maintained in humidified $95 \%$ air $/ 5 \% \quad \mathrm{CO}_{2}$ incubator at $37^{\circ} \mathrm{C}$.

\section{Neuro-protective activity of AS extract and phenolic compounds}

The MTT [3-(4,5-dimethylthiazol-2-yl)-2,5-diphenyl tetrazolium bromide] assay, described by Hansen et al. (1989), is a test of the cytotoxicity of reagents and of cell viability. Neuro 2A cells were seeded on a 96-well plate (5000 cells/well) and routinely grown in MEM $(1 \% \mathrm{FBS})$ for $48 \mathrm{~h}$. Cells were treated with aggregated $\mathrm{A} \beta_{25-35}(15 \mu \mathrm{M})$, and the viability was determined by MTT reduction. To determine the protective effects of AS extract and phenolic compounds on $\mathrm{A} \beta$-induced neurotoxicity, cell were treated with $\mathrm{A} \beta_{25-35}(15 \mu \mathrm{M})$ for $48 \mathrm{~h}$ in the presence or absence of AS extract (50-500 $\mu \mathrm{g} / \mathrm{ml})$, FA $(2-40 \mu \mathrm{g} / \mathrm{ml})$, phthalic acid $(20 \mu \mathrm{g} / \mathrm{ml})$, coumaric acid $(20 \mu \mathrm{g} / \mathrm{ml})$, and nicotinic acid $(20 \mu \mathrm{g} / \mathrm{ml})$. 
The phenolic acids were purchased from Sigma (St. Louis, MI, USA). MTT solution $(2 \mathrm{mg} / \mathrm{ml}$, in phosphate-buffer saline, PBS) was added to growing cultures. The OD was measured at $570 \mathrm{~nm}$ using a spectrophotometer (SPECTRAmax PLUS, Molecular Devices).

\section{Intracellular ROS production determination}

ROS production was monitored by flow cytometry, and DCF-DA, a relatively specific probe was used for the presence of hydrogen peroxide (LeBel and Bondy, 1990). Cells incubated in $6 \mathrm{~cm}$ dishes were treated with $\mathrm{A} \beta_{25-35}$ with and without AS extract for different time periods. DCF-DA $(10 \mu \mathrm{M})$ was added into the medium for a further $30 \mathrm{~min}$ at $37^{\circ} \mathrm{C}$. The cells were collected by pipetting, washed twice with PBS, and then analyzed by flow cytometry. The fluorescent dye-thioether adduct was excited at $488 \mathrm{~nm}$, and the fluorescence was collected with a $525 \mathrm{~nm}$ band pass filter. A total of 10,000 cells were analyzed with WinMDI 2.8 software.

\section{Lipid peroxidation assay (TBARS)}

Cells incubated in $10 \mathrm{~cm}$ dishes were treated with $\mathrm{A} \beta$ and with or without AS extract for $24 \mathrm{~h}$. The medium was replaced with PBS, and cells were triturated in PBS using a Pasteur pipette. The suspension was transferred to a $10-\mathrm{ml}$ test tube and then centrifuged at $1000 \mathrm{~g}$ for $30 \mathrm{~min}$. The pellets were re-suspended in $5 \mathrm{ml}$ of PBS containing $0.002 \%$ butylated hydroxy toluene (BHT) and re-centrifuged at $1000 \mathrm{~g}$ for $3 \mathrm{~min}$. The pellet was used to quantify lipid peroxides using the TBARS assay (Uchiyama and Mihara, 1978). Cell homogenates (prepared in $0.5 \mathrm{ml}$ PBS with $1 \%$ sodium dodecyl sulfate (SDS) from $4 \times 10^{6}$ cells/pellet) were mixed with $3 \mathrm{ml}$ of $1 \%$ phosphoric acid, $1 \mathrm{ml}$ of $0.67 \%$ thiobarbituric acid (TBA), and $0.04 \%$ BHT in glass test tubes, and the mixtures were incubated in a boiling water bath for $60 \mathrm{~min}$. Marbles were placed on the tops of tubes during the incubation period to avoid excessive loss of the reaction mixture. After cooling the tubes in ice, $1.5 \mathrm{ml}$ of $n$-butanol was added, and the reaction mixture was centrifuged at $1000 \mathrm{~g}$ for $10 \mathrm{~min}$. The absorbance of the supernatant was read at $532 \mathrm{~nm}$ and the concentrations of TBARS were determined.

\section{Measurement of intracellular GSH content by flow cytometry}

The level of intracellular GSH per cell was determined by flow cytometry after staining cells with CMF-DA (Chang et al., 2002). The CMF-DA was prepared as a $25 \mathrm{mM}$ solution in DMSO and stored at $-20^{\circ} \mathrm{C}$. Cells incubated in $6 \mathrm{~cm}$ dishes were treated with $\mathrm{A} \beta_{25-35}$ with and without AS extract for different time periods. The CMF-DA $(25 \mathrm{mM})$ was added in cell suspensions adjusted at $1-2 \times 10^{6}$ cells $/ \mathrm{ml}$. After $30 \mathrm{~min}$ of incubation at $37^{\circ} \mathrm{C}$, cells were washed twice in PBS, resuspended at a concentration of $10^{6}$ cells $/ \mathrm{ml}$ in PBS, and analyzed by flow cytometer. The fluorescent dyethioether adduct was excited at $488 \mathrm{~nm}$, and the fluorescence was collected with a $525 \mathrm{~nm}$ band pass filter. Analyses were performed on 10,000 cells with WinMDI 2.8 software.

\section{Measurement of mitochondrial membrane potential (MMP)}

The level of MMP was determined by flow cytometry after staining cells with rhodamine 123 (Rh123), a cationic lipophilic fluorochrome with a distribution to the mitochondrial matrix that correlates with the MMP (Sureda et al., 1997). Rh123 was added to the cell suspension at a final concentration of $5 \mu \mathrm{M}$, adjusted to $10^{6}$ cells $/ \mathrm{ml}$ in PBS. After incubation at $37^{\circ} \mathrm{C}$ for $30 \mathrm{~min}$, cells were washed and re-suspended in PBS for cytometry assay with the excitation wavelength at $488 \mathrm{~nm}$ and the emission wavelength at $523 \mathrm{~nm}$. Analyses were performed on 10,000 cells with WinMDI 2.8 software.

\section{Evaluation of mitochondrial mass}

The relative mitochondrial mass was measured using flow cytometry with 10- $n$-nonyl-acridine orange (NAO, a dye capable of binding mitochondria depending on their mass, in an energy-independent manner) (Maftah et al., 1989; Shishido et al., 2003). For NAO staining, the cells were trypsinized, re-suspended in PBS, and fixed in $70 \%$ ethanol for $18 \mathrm{~h}$ at $4{ }^{\circ} \mathrm{C}$. After ethanol was removed by centrifugation, the cells were washed in PBS and stained with $2 \mu \mathrm{M}$ NAO in PBS. After being incubated for $15 \mathrm{~min}$ at room temperature in the dark, the cells were washed in PBS and subjected to flow cytometric analysis. Bafilomycin A1 (50 nM), 3-methyladenine $(2 \mathrm{mM})$, was added to the cells $30 \mathrm{~min}$ before staining them with NAO.

\section{Electron microscopy analyses}

Cells were fixed in 3\% glutaraldehyde in $0.1 \mathrm{M}$ Mops buffer ( $\mathrm{pH} 7.0$ ) for $8 \mathrm{~h}$, at room temperature, then in $3 \%$ glutaraldehyde $/ 1 \%$ paraformaldehyde in $0.1 \mathrm{M}$ Mops buffer ( $\mathrm{pH} 7.0$ ) for $16 \mathrm{~h}$ at $4{ }^{\circ} \mathrm{C}$, postfixed in $1 \%$ osmium tetroxide for $1 \mathrm{~h}$, embedded, sectioned, double stained with uranyl acetate and lead citrate, and examined in a Hitachi H-600 (Tokyo, Japan) at $50 \mathrm{KV}$ at a magnification of 20,000 $\times$ (Yu et al., 2006). 


\section{Statistical analysis}

The results shown represent the mean \pm standard deviation from three independent experiments $(n=3)$. Statistical analysis was performed by ANOVA. The difference between the means was determined by Duncan's multiple range test.

\section{Results}

\section{Phenolic compounds of AS extract}

Fig. 1A displays a typical HPLC chromatogram of phenolic standards. The phenolic compounds of AS extracts were readily identified using HPLC-DAD by comparison with authentic standards. The HPLC profiles in Fig. 1B show the presence of nicotinic acid, phthalic acid, $p$-coumaric acid, and FA in AS extracts. The phenolic compound content in AS extracts is shown in Table 1 . The FA content $(1.63 \mathrm{mg} / \mathrm{g})$ was higher than that of other phenolic acids, nicotinic acid $(0.198 \mathrm{mg} / \mathrm{g})$, coumaric acid $(0.156 \mathrm{mg} / \mathrm{g})$, and phthalic acid $(0.041 \mathrm{mg} / \mathrm{g})$ in the AS extract.

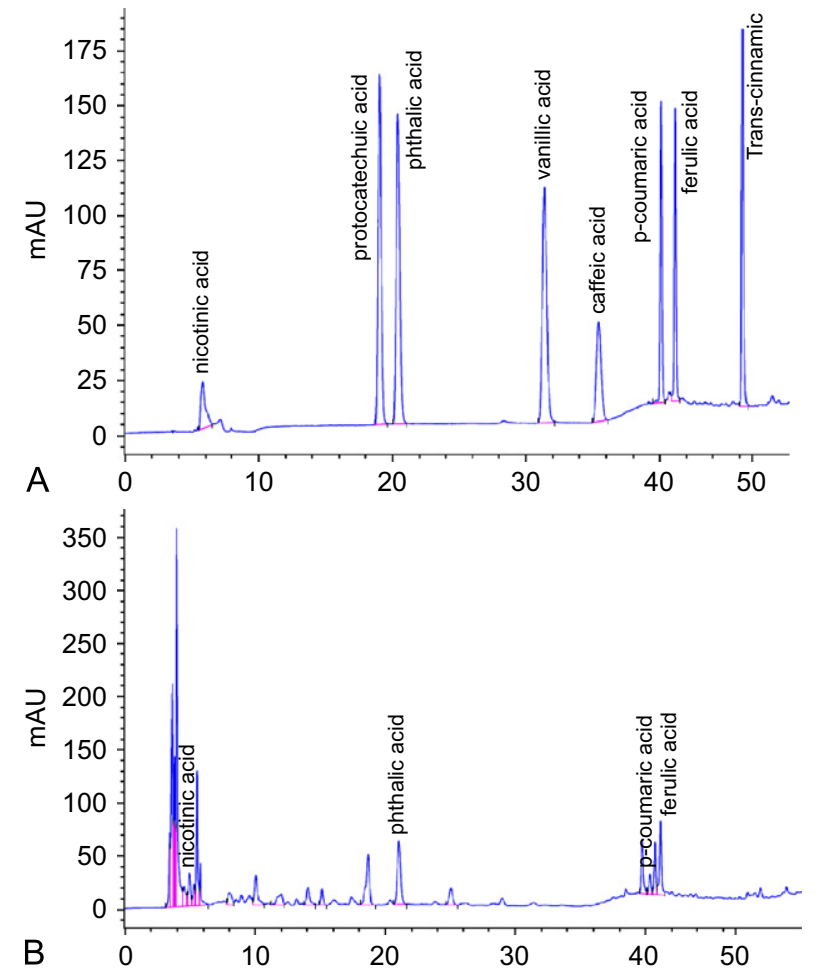

Fig. 1. Chromatogram of standard phenolic compounds (A) and AS extract of the root of Angelica sinensis (Oliv.) Diels (B) measured at $210 \mathrm{~nm}$. Analytical column: HS ODS column $(5 \mu \mathrm{m}, 250 \times 4.6 \mathrm{~mm})$ with ODS guard column $(5 \mu \mathrm{m}$, $4 \times 4 \mathrm{~mm}$ ); Sample injection volume: $20 \mu \mathrm{l}$; Mobile phase: solution $\mathrm{A}, 30 \mathrm{mM}$ potassium dihydrogen phosphate, $\mathrm{pH}=$ 3.5 , and solution $\mathrm{B}$, acetonitrile $/ \mathrm{H}_{2} \mathrm{O}=80 / 20$, flow rate: $0.8 \mathrm{ml} / \mathrm{min}$; temperature: ambient.
Table 1. Phenolic compounds in Angelica sinensis ethanol extracts

\begin{tabular}{lr}
\hline Phenolics & Content $(\mathrm{mg} / \mathrm{g})$ \\
\hline Total polyphenols GAE & $10.990 \pm 0.074$ \\
Nicotinic acid & $0.198 \pm 0.017$ \\
Phthalic acid & $0.041 \pm 0.003$ \\
Coumaric acid & $0.156 \pm 0.032$ \\
Ferulic acid & $1.630 \pm 0.037$
\end{tabular}

Mean \pm standard deviation $(n=3)$.

${ }^{\mathrm{a}} \mathrm{GAE}$ represents gallic acid equivalent.

\section{Neuro-protective activity of AS extract}

Fig. $2 \mathrm{~A}$ shows Neuro $2 \mathrm{~A}$ treated with $\mathrm{A} \beta(15 \mu \mathrm{M})$ for $48 \mathrm{~h}$ and untreated cell morphology. Treatment of Neuro $2 \mathrm{~A}$ cells with $\mathrm{A} \beta_{25-35}$ for $48 \mathrm{~h}$ decreased cell viability in a concentration-dependent manner $\left(\mathrm{IC}_{50}=\right.$ $14.9 \mu \mathrm{M}$ ), as determined by MTT assay (Fig. 2B). To characterize the protective effects of AS extract and phenolic acids on $\mathrm{A} \beta$-induced neurotoxicity, Neuro $2 \mathrm{~A}$ cells were treated with $\mathrm{A} \beta_{25-35}(15 \mu \mathrm{M})$ for $48 \mathrm{~h}$ in the presence or absence of AS extract or phenolic acids. The viability of $\mathrm{A} \beta$-treated cells was $57.0 \%$, and this increased to $72.0 \%$ with $200 \mu \mathrm{g} / \mathrm{ml}$ AS extract (Fig. 2C), and to $74.5 \%$ and $75.7 \%$ with $4 \mu \mathrm{g} / \mathrm{ml}$ of FA (Fig. 2D) and $20 \mu \mathrm{g} / \mathrm{ml}$ of phthalic acid (Fig. 2E), respectively, in the same treatment $(p<0.05)$.

\section{AS extract prevents A $\beta$-induced ROS accumulation}

$\mathrm{A} \beta$ is able to promote the generation of ROS, and this may be a relevant mechanism underlying the $\mathrm{A} \beta$ induced degeneration of nerve cells. We measured the intracellular contents of ROS in Neuro 2A cells that had been exogenously challenged with $15 \mu \mathrm{M} \mathrm{A} \beta$ for various time periods $(15,30,60,90$, and $120 \mathrm{~min})$. Green DCF fluorescence is generated when DCF-DA is hydrolyzed by esterase and oxidized by hydrogen peroxide. The FL1-H fluorescence intensity on a FACScan flow cytometer reflects the hydrogen peroxide concentration in living cells. Using DCF fluorescence as an indicator of ROS levels, the fluorescence intensity of Neuro 2A cells attained a high level within $15 \mathrm{~min}$ of treatment and then declined over time (Fig. 3A). The elevated hydrogen peroxide level of $\mathrm{A} \beta$-treated $(15 \mu \mathrm{M})$ Neuro $2 \mathrm{~A}$ cells was reduced by the addition of AS extract $(0,50,100$, and $200 \mu \mathrm{g} / \mathrm{ml}$ ) in a dose-dependent manner (Fig. 3B). These results showed that the FL1-H intensity of $\mathrm{A} \beta$-treated cells was suppressed by AS extract.

\section{AS extract prevented $A \beta$-induced lipid peroxidation}

Polyunsaturated fatty acids in membrane lipids are prone to be attacked by ROS, and the resulting lipid 

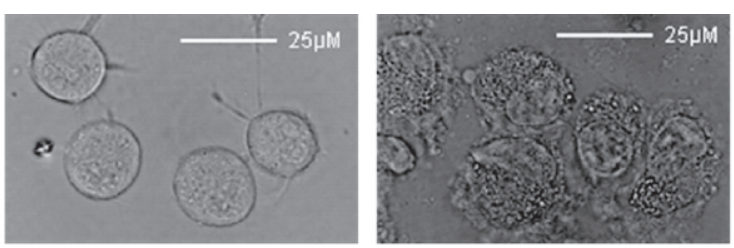

A
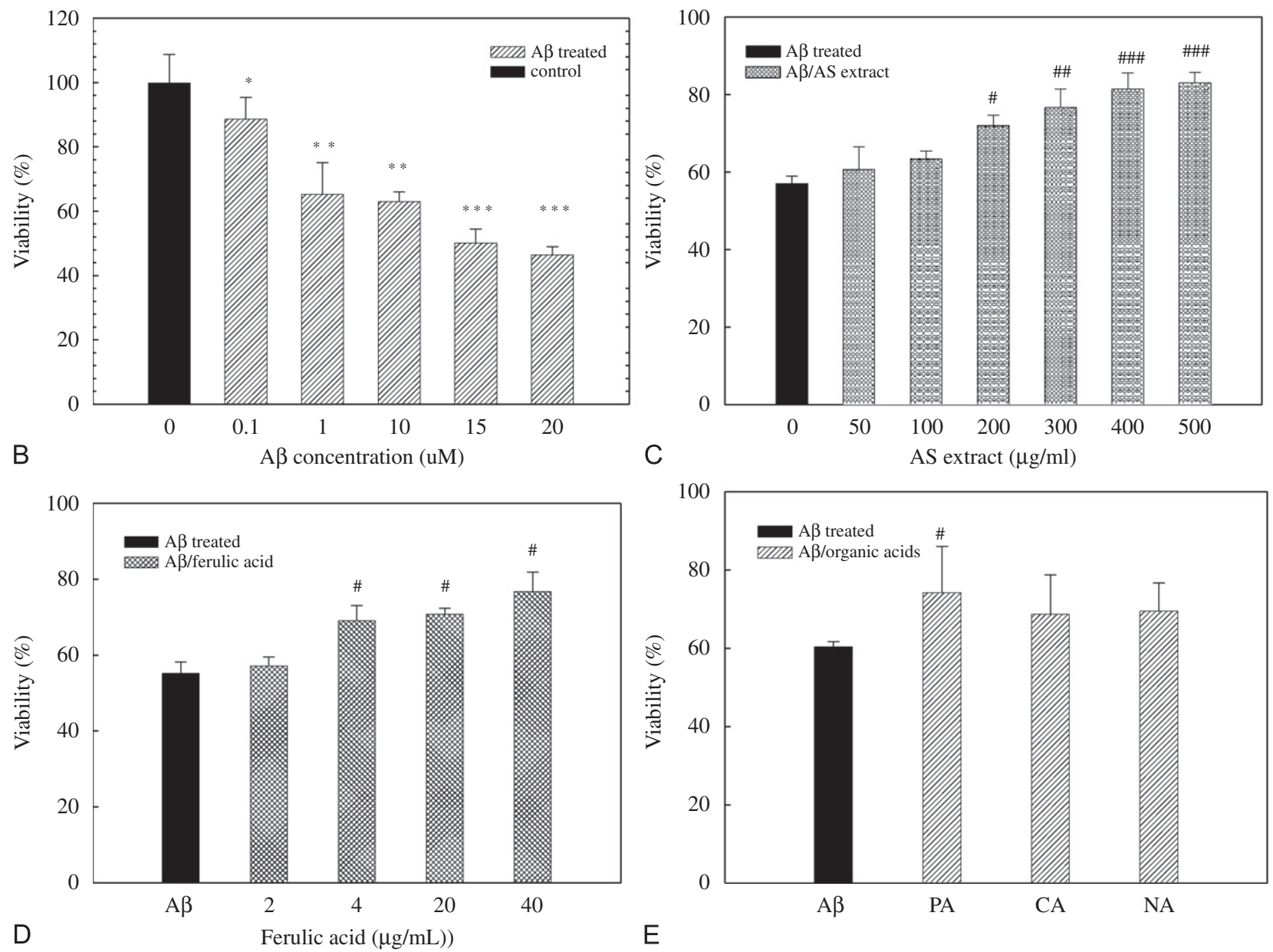

Fig. 2. Beta-amyloid (A $\beta$ ) peptide untreated (left panel) and treated (15 $\mathrm{MM}$ for $48 \mathrm{~h}$ ) (right panel) Neuro $2 \mathrm{~A}$ Cell Morphology (A), A $\beta$-induced neurotoxicity on mouse Neuro $2 \mathrm{~A}$ cells. ${ }^{*} p<0.05,{ }^{*} p<0.01$, and ${ }^{* * *} p<0.001$ (compared with control) (B). The protective effect of AS extract (C), ferulic acid (D), and phenolic acids (E) on A $\beta$-induced neurotoxicity. ${ }^{\#} p<0.05$, ${ }^{\# \#} p<0.01$, and

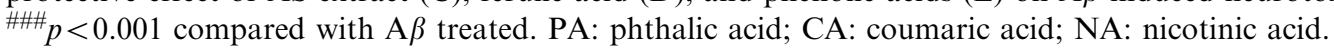

peroxide can cause injury and cell death. Generation of cellular lipid peroxides by $\mathrm{A} \beta$ treatment was assessed using TBARS assay, in which equal amounts of cell lysate reacted with TBA, and the resulting complex was estimated by taking absorbance at $532 \mathrm{~nm}$. The Neuro $2 \mathrm{~A}$ cells treated with $\mathrm{A} \beta_{25-35}(15 \mu \mathrm{M})$ for $24 \mathrm{~h}$ resulted in a significant increase in lipid peroxidation. Treatment of Neuro 2A cells with 50,100 , and $200 \mu \mathrm{g} / \mathrm{ml}$ of AS extract reduced the $\mathrm{A} \beta$-induced lipid peroxidation to $79 \%, 79 \%$, and $73 \%$ of the control $(p<0.05)$, respectively (Fig. 4). Our experiment also showed that the AS extract did not inhibit the proliferation of Neuro 2A cells at dosages below $500 \mu \mathrm{g} / \mathrm{ml}$ (data not shown).

\section{AS extract prevented A $\beta$-induced depletion of intracellular GSH content}

Glutathione (GSH) is the principal intracellular nonprotein thiol, and it provides a primary defense against oxidation stress through its ability to scavenge free radicals. Levels of GSH in Neuro 2A cells were determined using flow cytometry with the fluorescence probe CMF-DA (Fig. 5A), and it was found that $\mathrm{A} \beta$ treatment $(15 \mu \mathrm{M})$ for $1 \mathrm{~h}$ significantly depleted the intracellular GSH content. The A $\beta$-treated cells had only $79 \%$ of the GSH of the untreated control. Treatment of Neuro 2A cells with $200 \mu \mathrm{g} / \mathrm{ml}$ of AS 

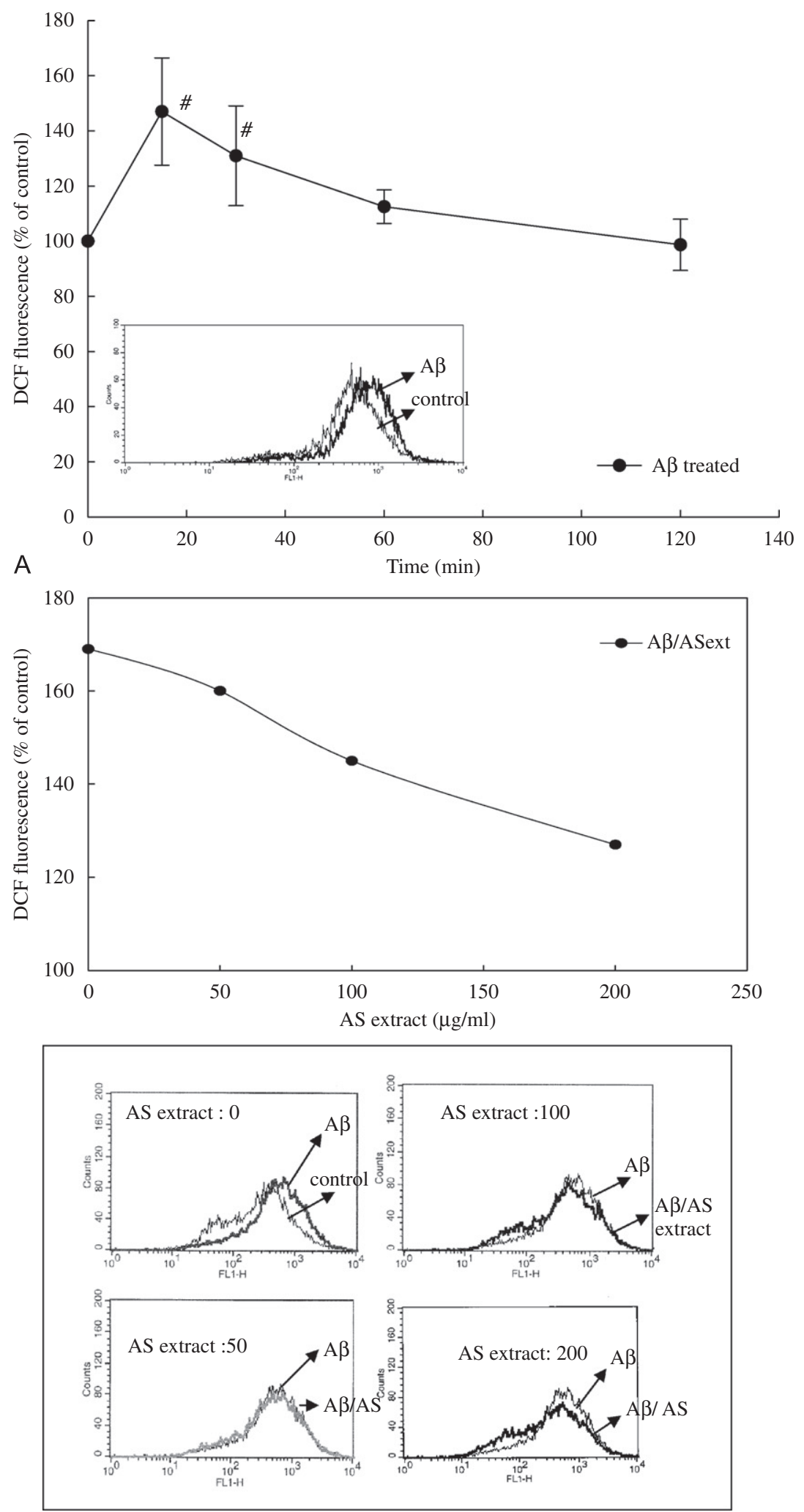

B

Fig. 3. Effect of AS extract on A $\beta$-induced intracellular accumulation of ROS in Neuro $2 \mathrm{~A}$ cells. (A) Cells were treated with $\mathrm{A} \beta_{25-35}$ $(15 \mu \mathrm{M})$ for different time periods. (B) Neuro $2 \mathrm{~A}$ cells exposed to $15 \mu \mathrm{M} \mathrm{A} \beta$ plus $50-200 \mu \mathrm{g} / \mathrm{ml}$ of AS extract for $15 \mathrm{~min}$. ${ }^{\#} p<0.05$. 


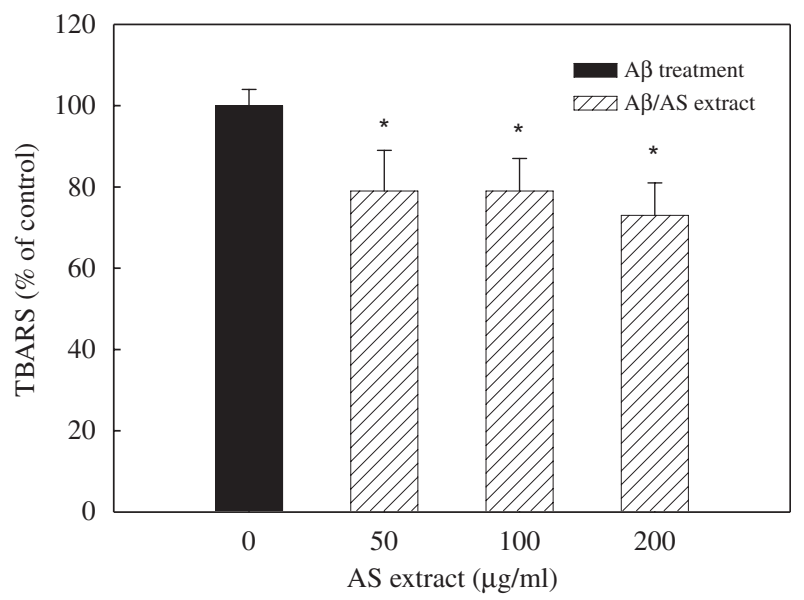

Fig. 4. Effect of AS extract against $\mathrm{A} \beta$-induced TBARS formation. Neuro $2 \mathrm{~A}$ cells were exposed to $\mathrm{A} \beta(15 \mu \mathrm{M})$ in the presence and absence of AS extract $(50,100$, and $200 \mu \mathrm{g} / \mathrm{ml})$. The values represent mean $\pm \mathrm{SD}$. ${ }^{*} p<0.05$ compared with $\mathrm{A} \beta$ treated.
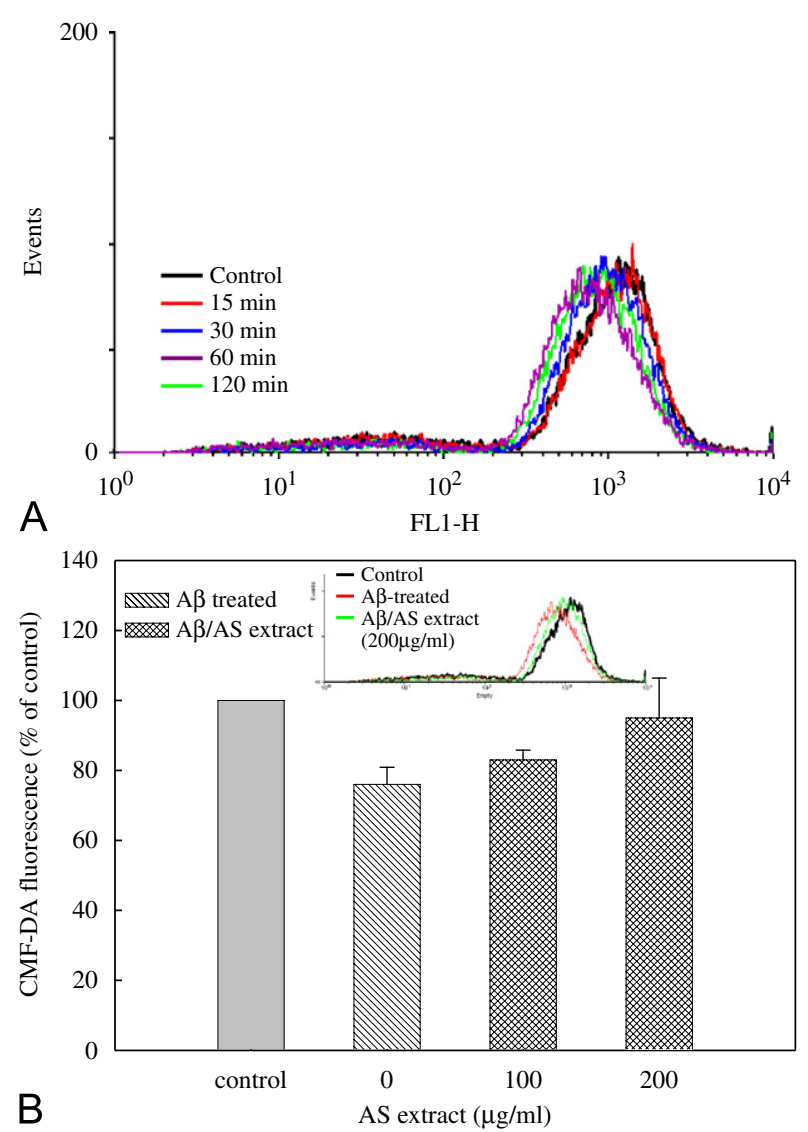

Fig. 5. Effect of AS extract on $A \beta$-induced intracellular GSH content in Neuro 2A cells. (A) Histograms for CMF-DA fluorescence shown in Neuro $2 \mathrm{~A}$ cells treated with $\mathrm{A} \beta_{25-35}$ $(15 \mu \mathrm{M})$ for different time periods. (B) Neuro $2 \mathrm{~A}$ cells were treated with $15 \mu \mathrm{M} \mathrm{A} \beta_{25-35}$ and $100,200 \mu \mathrm{g} / \mathrm{ml} \mathrm{AS}$ extract for $60 \mathrm{~min}$. extract completely prevented the $\mathrm{A} \beta$-induced depletion of intracellular GSH content (Fig. 5B).

\section{AS extract prevented $A \beta$-induced loss of mitochondrial membrane potential}

A change in mitochondrial inner transmembrane potential $(\Delta \Psi \mathrm{m})$ is a key indicator in programmed cell death. Levels of $\Delta \Psi \mathrm{m}$ in Neuro $2 \mathrm{~A}$ cells were determined using flow cytometry with the fluorescence probe rhodamine 123 (Fig. 6A). It was found that $\mathrm{A} \beta$ treatment $(15 \mu \mathrm{M})$ for $4 \mathrm{~h}$ yielded a significant decrease of $\Delta \Psi \mathrm{m}$, to approximately $66 \%$ of untreated control. Treatment of Neuro 2A cells with AS extract restored the $\Delta \Psi \mathrm{m}$ levels of $\mathrm{A} \beta$-induced $\mathrm{MMP}$ in a dosedependent manner. The dosages of $25,50,100$, and $200 \mu \mathrm{g} / \mathrm{ml}$ recovered $77 \%, 87 \%, 102 \%$, and $105 \%$, respectively, of the $\Delta \Psi \mathrm{m}$ as compared to the untreated control (Fig. 6B).

\section{Evaluation of mitochondrial mass and electron microscopy analysis}

Type II programmed cell death or autophagic cell death involves the accumulation of autophagic vacuoles (AV) in the cytoplasm of dying cells as well as enlargement of the mitochondrial mass. Neuro 2A cells were treated with $\mathrm{A} \beta_{25-35}(15 \mu \mathrm{M})$ for $48 \mathrm{~h}$, and the morphological ultrastructure of $\mathrm{A} \beta$-treated cells was examined by transmission electron microscope (TEM). Portions of the cytoplasm appeared sequestered by a membrane-bound vacuole (Fig. 7A). Autophagosomes or residual bodies in cells were markedly reduced in the presence of AS extract in culture medium. The fluorescent probe, NAO, interacting stoichiometrically with non-oxidized cardiolipin, is routinely used to measure the mitochondrial content of cells. A significant increase $(122 \%)$ in the mitochondrial mass of the Neuro $2 \mathrm{~A}$ cells relative to the untreated cells was revealed by $\mathrm{NAO}$ analysis after $\mathrm{A} \beta$ treatment for $48 \mathrm{~h}$ (Fig. 7B). The markedly enlarged mitochondria were also observed on TEM (Fig. 7A, left panel). Since the increases in NAO fluorescence of $\mathrm{A} \beta$-treated Neuro 2A cells suggested an increase of the cardiolipin content as a result of an enlargement of the mitochondrial mass, treatment of Neuro 2A cells with the autophagy-specific inhibitors was expected to reverse the increased NAO fluorescence. Bafilomycin A1 and 3-methyladenine, known to be autophagy inhibitors (Paglin et al., 2001; Kim and Klionsky, 2000; Blommaart et al., 1997), did indeed reduce NAO fluorescence $(89 \%$ and $91 \%$, respectively, in comparison with $\mathrm{A} \beta$-treated cells) in $\mathrm{A} \beta$-treated Neuro 2A cells (Fig. 7B), suggesting that A $\beta$-induced cell death may be mediated by autophagy. To observe the effect of AS extract on the elevation of NAO 

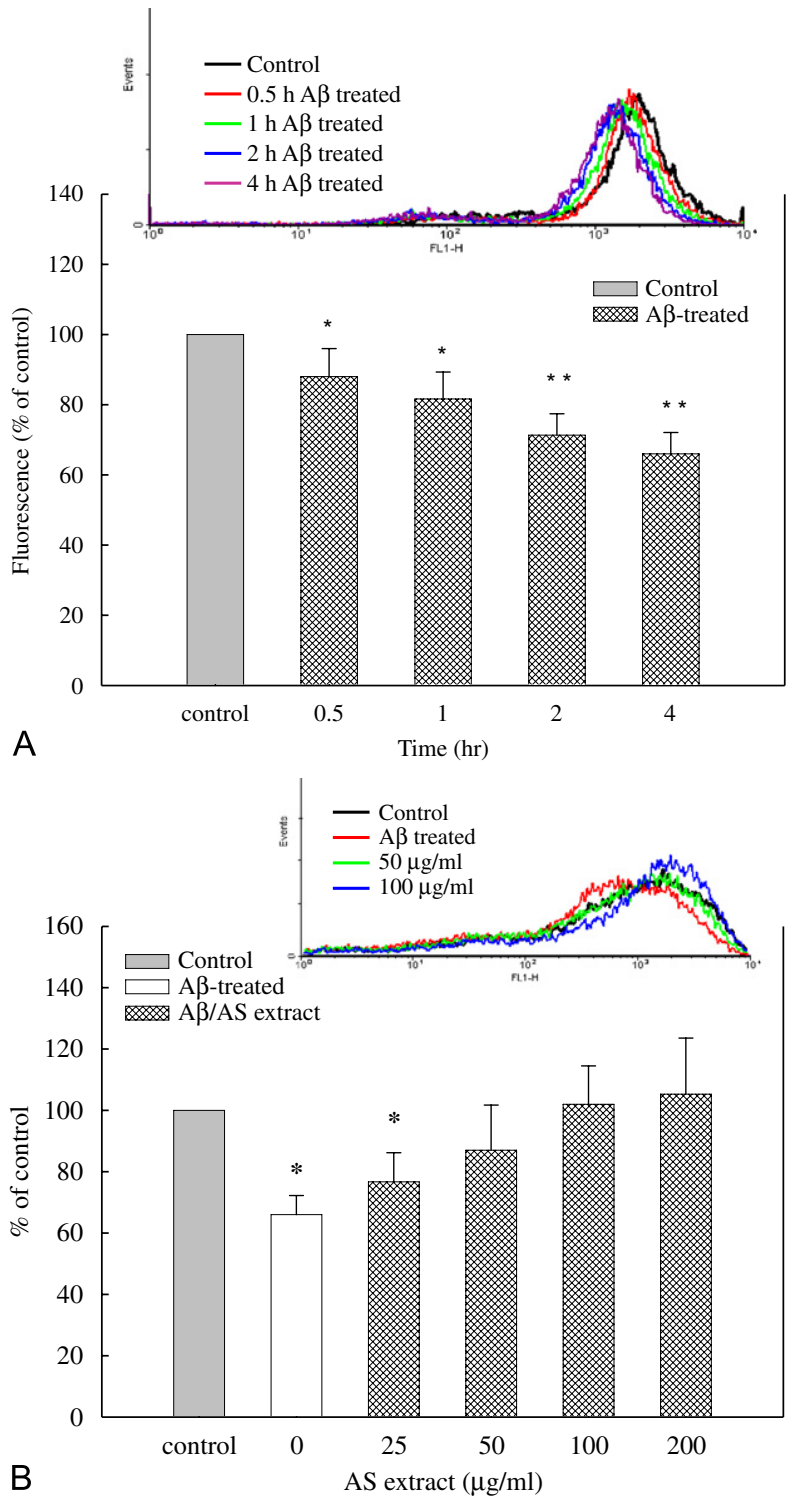

Fig. 6. Effect of AS extract on loss of $\Delta \Psi \mathrm{m}$ induced by $\mathrm{A} \beta$ in Neuro 2A cells. (A) Histograms for Rh123 fluorescence shown in Neuro $2 \mathrm{~A}$ cells treated with $15 \mu \mathrm{M} \mathrm{A} \beta_{25-35}$ for $0.5,1,2,4 \mathrm{~h}$. (B) Neuro 2A cells were treated with $25-200 \mu \mathrm{g} / \mathrm{ml} \mathrm{AS} \mathrm{extract}$ and $15 \mu \mathrm{M} \mathrm{A} \beta_{25-35}$ for $4 \mathrm{~h}$. ${ }^{*} p<0.05$ compared with control.

fluorescence by $\mathrm{A} \beta$ treatment, various dosages of $\mathrm{AS}$ extract $(25,50,100$, and $200 \mu \mathrm{g} / \mathrm{ml})$ were added to the cell culture along with $\mathrm{A} \beta$. The results showed that the NAO fluorescence of $\mathrm{A} \beta$-treated cells was suppressed by AS extract (Fig. 7B). Such a reduction in NAO fluorescence suggests that AS is effective at preventing $\mathrm{A} \beta_{25-35}$-induced neurotoxicity and is, like bafilomycin A1 and 3-methyladenine, mediated by autophagy.

\section{Discussion}

More than 10 components including ligustilide and FA have been identified in Radix Angelicae sinensis extract (Mao et al., 2002). FA, the main active components of AS found in the non-aromatic fractions, has been reported to have many physiological functions, including antioxidant, anti-inflammatory, anti-thrombosis, and anti-cancer activities (Ono and Yamada, 2006; Antony et al., 2004; Ou and Kwok, 2004; Yogeeta et al., 2006). FA and related compounds like vanillic acid, cinnamic acid, and coumaric acid reduced free radical damage in neuronal cell systems without themselves causing cell death (Kanski et al., 2002). Long-term oral administration of FA significantly reduced $\mathrm{A} \beta_{1-42}$-induced memory impairment in mice (Yan et al., 2001). During our studies, AS extract was prepared in a manner that replicated traditional Chinese medicine processing of AS. A dose of $200 \mu \mathrm{g} / \mathrm{ml}$ of AS extract exerted significant protective effects against $\mathrm{A} \beta$-induced neurotoxicity $(p<0.05)$. We also assessed the protective effects of FA in this experiment and found that a $4 \mu \mathrm{g} / \mathrm{ml}$ treatment could significantly increase cell viability $(p<0.05)$ (Fig. 2 C). It can be estimated that $200 \mu \mathrm{g} / \mathrm{ml}$ of AS extract contains $0.326 \mu \mathrm{g} / \mathrm{ml}$ of FA according to the results in Table 1 . This implied that components other than FA also contribute to the protective effect against $\mathrm{A} \beta$ toxicity. AS extract contains other organic acids, including nicotinic, phthalic, and coumaric acid (Table 1). Phthalic acid $(20 \mu \mathrm{g} / \mathrm{ml})$ also increased cell viability significantly $(p<0.05)$ (Fig. 2C) and acted against $\mathrm{A} \beta$-induced neurotoxicity, though neither coumaric acid nor nicotinic acid showed significant protective effects at the same dosage. However, $200 \mu \mathrm{g} / \mathrm{ml}$ of AS extract contains only $8.2 \mathrm{ng} / \mathrm{ml}$ of phthalic acid. The amount of FA plus phthalic acid in AS extract failed to reach the effective treatment dosage $(20 \mu \mathrm{g} / \mathrm{ml})$. Thus the beneficial effect of AS is likely due to unidentified compounds, such as conifery ferulate (Li et al., 2007), present in the extract or to the synergistic action of FA, phthalic acid, nicotinic acid, coumaric acid, and various other compounds such as ligustilide, levistulide, and falcarindiol.

The cytotoxicity by $\mathrm{A} \beta$ treatment has been found associated with oxidative stress. Several markers of excess oxidative stress, such as an increase in ROS, accumulation of oxidized products like protein carbonyls from protein oxidation and aldehydes and isoprostanes from lipid peroxidation, confirms the direct role of $\mathrm{A} \beta$ in the oxidative damage associated with $\mathrm{AD}$ (Miranda et al., 2000). Although the use of antioxidants has been recognized as an effective method in minimizing pathological and toxic effects associated with oxidative stress (Ono et al., 2006). This study showed that the AS extract exerts antioxidative activities that prevent $\mathrm{A} \beta$ cytotoxicity and do not themselves cause neuronal cell death.

GSH is an important intracellular antioxidant and essential cofactor for antioxidant enzymes that protects against endogenous oxygen radicals. Glutathione 

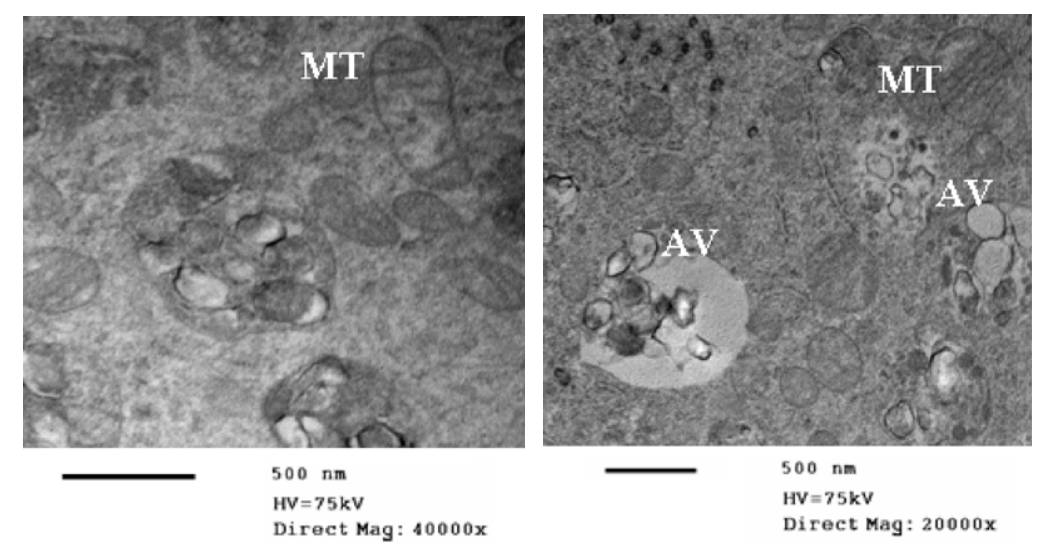

A

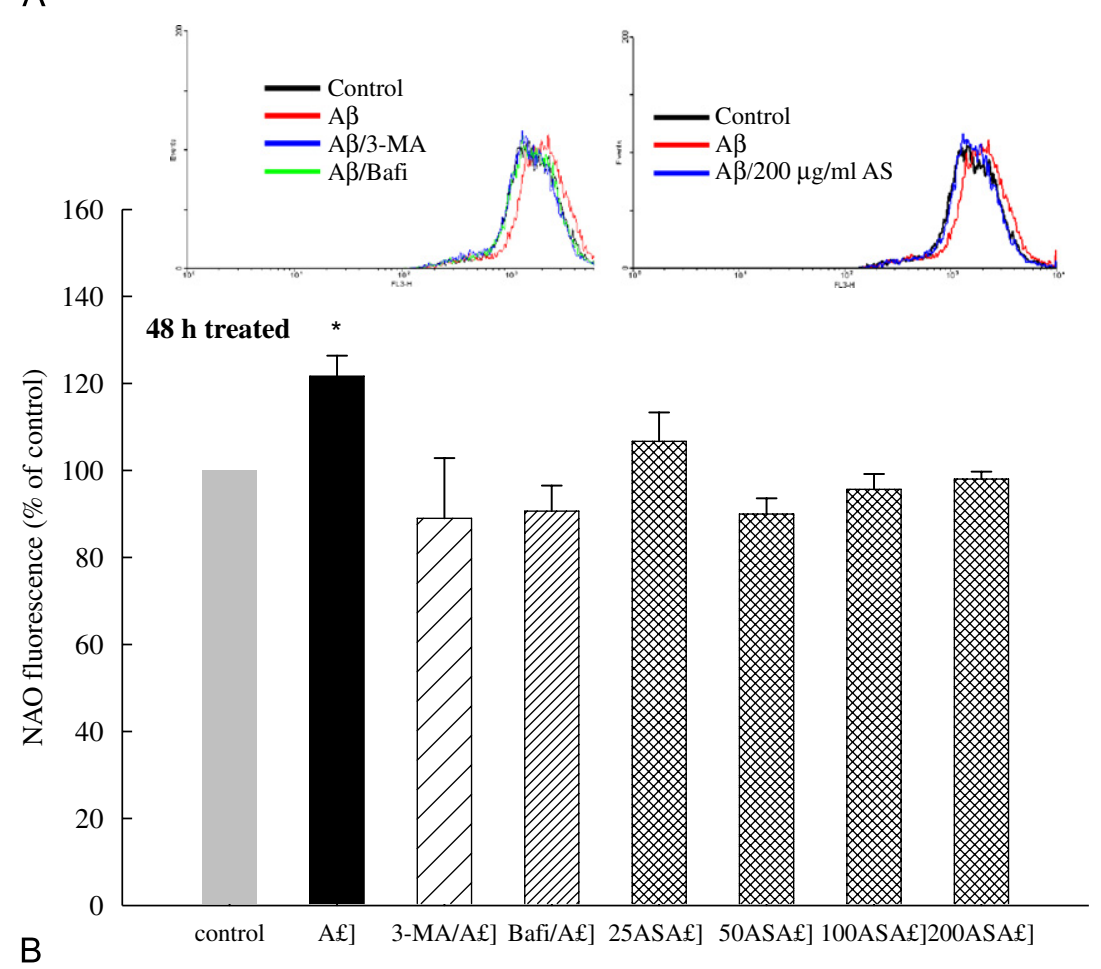

Fig. 7. Ultrastructure of Neuro $2 \mathrm{~A}$ cells after $\mathrm{A} \beta_{25-35}$ treatment. Neuro $2 \mathrm{~A}$ cells treated with $15 \mu \mathrm{M} \mathrm{A} \beta$ for $48 \mathrm{~h}$, and the autophagic vacuoles (AV) (A, right) and enlarged mitochondria (MT) (A, left) were observed. (B) Effect of $A \beta_{25-35}$ on mitochondrial mass in Neuro $2 \mathrm{~A}$ cells. Representative histograms for NAO fluorescence shown in Neuro $2 \mathrm{~A}$ cells treated with $15 \mu \mathrm{M} \mathrm{A} \beta_{25-35}$ for $48 \mathrm{~h}$ along with Bafilomycin A1 (Bafi, $50 \mathrm{nM}$ ), 3-methyladenine (3-MA, $2 \mathrm{mM}$ ) or AS extract $(25-200 \mu \mathrm{g} / \mathrm{ml})$.

disulfide (GSSG) is referred to as oxidized GSH. Disturbance of GSH homeostasis may either lead to or result from oxidative stress in neurodegenerative disorders (Schulz et al., 2000). Increasing evidence shows that GSH plays an important role in the detoxification of ROS in the brain (Dringen, 2000). The elevated ratio of GSSG to GSH in Parkinson's disease (PD) is consistent with the concept of oxidative stress as an important component in the pathogenesis of PD (Sian et al., 1994). The lowered GSH content appears to be the first indicator for oxidative stress during the progression of PD and AD (Nakamura et al., 1997; Woltjer et al., 2005). It has been reported that oxidative stress plays a role in the pathogenic process but that alterations in the GSH system are secondary to other events leading to neurodegeneration. Therefore, it remains debatable whether this is a primary defect or only a consequence of ROS generation. Nevertheless, AS extract treatment may either lead to enhanced synthesis of GSH or inhibition of its degradation, resulting in a slowing of $\mathrm{A} \beta$-induced autophagy signaling. The increase of GSH content upon AS extract treatment will result in a clinical benefit and/or neuroprotection in $\mathrm{A} \beta$-associated diseases.

Mitochondria play a central role in regulating cell death and survival. Oxidative damage has been shown 
to increase the permeability of the mitochondrial membrane and result in mitochondrial failure. Increased mitochondrial permeability is accompanied by depolarization of the mitochondrial membrane and uncoupling of oxidative phosphorylation reactions in the mitochondrial lumen. In the present study, we demonstrated a significant increase in mitochondrial volume in the Neuro $2 \mathrm{~A}$ cells treated with $\mathrm{A} \beta_{25-35}$. Enlarged mitochondria have been considered to be a cytopathic manifestation, occasionally leading to cell death (Karbowski et al., 1999). Based on this point of view, we focused on the $\mathrm{A} \beta$-related mitochondrial dysfunction in the Neuro $2 \mathrm{~A}$ cells by means of measuring the $\Delta \Psi \mathrm{m}$, because reduction in $\Delta \Psi \mathrm{m}$ is an early and sensitive indicator of cellular damage, preceding Adenosine 5 '-triphosphate (ATP) depletion and increased membrane permeability (Marchetti et al., 1996). A $\beta$-treated cells showed a decrease in $\Delta \Psi \mathrm{m}$, indicating the intoxication not only leads to morphologic alterations but also to function damage in mitochondria.

Cell death has been subdivided into three categories: apoptosis (Type I), autophagic cell death (Type II), and necrosis (Type III). The boundary between Types I and II has never been completely clarified and perhaps does not exist due to intrinsic factors among different cell types and the crosstalk among organelles within each type (Lockshin and Zakeri, 2001, 2004). In AD, mechanisms of programmed cell death and especially apoptosis have been suggested (Kienlen-Campard et al., 2002). However, autophagic cell death of neurons has been reported in patients with Huntington disease, PD, and AD (Anglade et al., 1997; Webb et al., 2003; Cataldo et al., 1994). All these in vivo observations suggest a functional role for autophagy in neuronal cell death. To clarify the type of cell death that occurs under A $\beta$ treatment, an apoptosis characteristic analysis including DNA fragmentation, sub-G1 peak of propidium iodide flowcytometry, and FITC/PI flowcytometry was carried out. The results suggest that $\mathrm{A} \beta_{25-35}$ peptide-induced neurotoxicity is not associated with apoptosis (data not shown). This observation is consistent with some of the existing reports. Misiti et al. (2005) also reported that $\mathrm{A} \beta_{31-35}$ peptide-induced neurotoxicity in PC12 cells via an apoptosis cell death pathway, but this neurotoxicity was not associated with any of the biochemical features of apoptosis. Yang and coworker's findings suggested that neuronal death in PS/APP mice was not apoptosis though the apoptotic cascade might have been activated to some degree in some neurons (Yang et al., 2004). In the current study, treatment of Neuro 2A cells with the autophagy-specific inhibitors, Bafilomycin A1 and 3-methyladenine, suggested that $\mathrm{A} \beta$-induced cell death may be mediated by autophagy. This study also showed that AS extract had effects similar to autophagy-specific inhibitors on Neuro $2 \mathrm{~A}$ cells, suggesting that $\mathrm{AS}$ is effective at preventing
$\mathrm{A} \beta_{25-35}$-induced neurotoxicity, which is perhaps mediated by autophagy.

\section{Acknowledgments}

This study was supported by a Grant from the National Science Council (NSC 94-2214-E-002-014).

\section{References}

Anglade, P., Vyas, S., Javoy-Agid, F., Herrero, M.T., Michel, P.P., Marquez, J., Mouatt-Prigent, A., Ruberg, M., Hirsch, B.C., Agid, Y., 1997. Apoptosis and autophagy in nigral neurons of patients with Parkinson's disease. Histol. Histopathol. 12, 25-31.

Antony, J.M., van Marle, G., Opii, W., Butterfield, D.A., Mallet, F., Yong, V.W., Wallace, J.L., Deacon, R.M., Warren, K., Power, C., 2004. Human endogenous retrovirus glycoprotein-mediated induction of redox reactants causes oligodendrocyte death and demyelination. Nat. Neurosci. 7, 1088-1095.

Blommaart, E.F., Luiken, J.J., Meije, A.J., 1997. Autophagic proteolysis: control and specificity. Histochem. J. 29, 365-385.

Butterfield, D.A., Kanski, J., 2001. Brain protein oxidation in age-related neurodegenerative disorders that are associated with aggregated protein. Mech. Aging Dev. 122, 945-962.

Cataldo, A.M., Hamilton, D.J., Nixon, R.A., 1994. Lysosomal abnormalities in degenerating neurons link neuronal compromise to senile plaque development in Alzheimer disease. Brain Res. 640, 68-80.

Chang, W.H., Chen, C.H., Lu, F.J., 2002. Different effects of baicalein, baicalin and wogonin on mitochondrial function, glutathione content and cell cycle progression in human hepatoma cell lines. Planta Med. 68, 128-132.

Dringen, R., 2000. Metabolism and functions of glutathione in brain. Prog. Neurobiol. 62, 649-671.

Hansen, M.B., Nielsen, S.E., Berg, K., 1989. Re-examination and further development of a precise and rapid dye method for measuring cell growth/cell kill. J. Immunol. Methods 119, 203-210.

Heo, H.J., Kim, D.O., Choi, S.J., Shin, D.H., Lee, C.Y., 2004. Potent inhibitory effect of flavonoids in Scutellaria baicalensis on amyloid $\beta$ protein-induced neurotoxicity. J. Agric. Food Chem. 52, 4128-4132.

Hsu, H-Y., Peacher, W.G., 1976. Chinese Herb Medicine and Therapy. Aurora Publishers Incorporated, Nashville, TN, USA.

Kanski, J., Aksenova, M., Stoyanova, A., Butterfield, D.A., 2002. Ferulic acid antioxidant protection against hydroxyl and peroxyl radical oxidation in synaptosomal and neuronal cell culture system in vitro: structure-activity studies. J. Nutr. Biochem. 13, 273-281.

Karbowski, M., Kurono, C., Wozniak, M., Ostrowski, M., Teranish, M., Nishizawa, Y., Usukura, J., 1999. Free radical-induced megamitochondria formation and apoptosis. Free Radic. Biol. Med. 26, 396-409. 
Kienlen-Campard, P., Miolet, S., Tasiaux, B., Octave, J.N., 2002. Intracellular amyloid-beta 1-42, but not extracellular soluble amyloid-beta peptide, induces neuronal apoptosis. J. Biol. Chem. 277, 15666-15670.

Kim, J., Klionsky, D.J., 2000. Autophagy, cytoplasm-tovacuole targeting pathway, and pexophagy in yeast and mammalian cells. Annu. Rev. Biochem. 69, 303-342.

LeBel, C.P., Bondy, S.C., 1990. Sensitive and rapid quantitation of oxygen reactive species formation in rat synaptosomes. Neurochem. Int. 17, 435-441.

Li, S.Y., Yu, Y., Li, S.P., 2007. Identification of antioxidants in essential oil of Radix Angelica sinensis using HPLC coupled with DAD-MS and ABTS-based assay. J. Agric. Food Chem. 55, 3358-3362.

Lockshin, R.A., Zakeri, Z., 2001. Programmed cell death and apoptosis: origins of the theory. Nat. Rev. Mol. Cell Biol. 2, 545-550.

Lockshin, R.A., Zakeri, Z., 2004. Apoptosis, autophagy, and more. Int. J. Biochem. Cell Biol. 36, 2405-2419.

Lu, G.H., Chan, K., Leung, K., Chan, C.L., Zhao, Z.Z., Jiang, Z.H., 2005. Assay of free ferulic acid and total ferulic acid for quality assessment of Angelica sinensis. J. Chromatogr. A 1068, 209-219.

Lyras, L., Cairns, N.J., Jenner, A., Jenner, P., Halliwell, B., 1997. An assessment of oxidative damage to proteins, lipid and DNA in brain from patients with Alzheimer's disease. J. Neurochem. 68, 2061-2069.

Maftah, A., Petit, J.M., Ratinaud, M.H., Julien, R., 1989. 10$n$-nonyl-acridine orange: a fluorescent probe which stains mitochondria independently of their energetic state. Biochem. Biophys. Res. Commun. 164, 185-190.

Mao, X., Kong, L., Luo, Q., Li, X., Zou, H., 2002. Screening and analysis of permeable compounds in Radix Angelica sinensis with immobilized liposome chromatography. J. Chromatogr. B 779, 331-339.

Marchetti, P., Castedo, M., Susin, S.A., Zamzami, N., Hirsch, T., Macho, A., Haeffner, A., 1996. Mitochondrial permeability transition is a central coordinating event of apoptosis. J. Exp. Med. 184, 1155-1160.

Miranda, S., Opazo, C., Larrondo, L.F., Muñoz, F.J., Ruiz, F., Leighton, F., Inestrosa, N.C., 2000. The role of oxidative stress in the toxicity induced by amyloid $\beta$ peptide in Alzheimer's disease. Prog. Neurobiol. 62, 633-648.

Misiti, F., Sampaolese, B., Pezzotti, M., Marini, S., Coletta, M., Ceccarelli, L., Giardina, B., Clementi, ME., 2005. $\mathrm{A} \beta_{(31-35)}$ peptide induce apoptosis in PC12 cells: contrast with $\mathrm{A} \beta_{(25-35)}$ peptide and examination of underlying mechanisms. Neurochem. Int. 46, 575-583.

Nakamura, K., Wang, W., Kang, U.J., 1997. The role of glutathione in dopaminergic neuronal survival. J. Neurochem. 69, 1850-1858.

Ono, K., Yamada, M., 2006. Antioxidant compounds have potent anti-fibrillogenic and fibril-destabilizing effects for alpha-synuclein fibrils in vitro. J. Neurochem. 97, 105-115.

Ono, K., Hamaguchi, T., Naiki, H., Yamada, M., 2006. Antiamyloidogenic effects of antioxidants: implications for the prevention and therapeutics of Alzheimer's disease. Biochim. Biophys. Acta 1762, 575-586.
Ou, S., Kwok, K.C., 2004. Ferulic acid: pharmaceutical functions, preparation and applications in foods. J. Sci. Food Agric. 84, 1261-1269.

Paglin, S., Hollister, T., Delohery, T., Hackett, N., McMahill, M., Sphicas, E., Domingo, D., Yahalom, J., 2001. A novel response of cancer cells to radiation involves autophagy and formation of acidic vesicles. Cancer Res. 61, 439-444.

Schulz, J.B., Lindenau, J., Seyfried, J., Dichgans, J., 2000. Glutathione, oxidative stress and neurodegeneration. Eur. J. Biochem. 267, 4904-4911.

Shishido, S., Koga, H., Harada, M., Kumemura, H., Hanada, S., Taniguchi, E., Kumashiro, R., Ohira, H., Sato, Y., Namba, M., Ueno, T., Sata, M., 2003. Hydrogen peroxide overproduction in megamitochondria of troglitazone-treated human hepatocytes. Hepatology 37, 136-147.

Sian, J., Dexter, D.T., Lees, A.J., Daniel, S., Agid, Y., JavoyAgid, F., Jenner, P., Marsden, C.D., 1994. Alterations in glutathione levels in Parkinson's disease and other neurodegenerative disorders affecting basal ganglia. Ann. Neurol. 36, 348-355.

Sureda, F.X., Escubedo, E., Gabriel, C., Comas, J., Camarasa, J., Camins, A., 1997. Mitochondria membrane potential measurement in rat cerebellar neurons by flow cytometry. Cytometry 28, 74-80.

Uchiyama, M., Mihara, M., 1978. Determination of malonaldehyde precursor in tissue by thiobarbituric acid test. Anal. Biochem. 86, 271-278.

Varadarajan, S., Yatin, S., Aksenova, M., Butterfield, D.A., 2000. Review: Alzheimer's amyloid $\beta$-peptide-associated free radical oxidative stress and neurotoxicity. J. Struct. Biol. 130, 184-208.

Wang, C.N., Chi, C.W., Lin, Y.L., Chen, C.F., Shiao, Y.J., 2001. The neuroprotective effects of phytoestrogens on amyloid $\beta$ protein-induced toxicity are mediated by abrogating the activation of caspase cascade in rat cortical neurons. J. Biol. Chem. 276, 5287-5295.

Webb, J.L., Ravikumar, B., Atkins, J., Skepper, J.N., Rubinsztein, D.C., 2003. Alpha-synuclein is degraded by both autophagy and the proteasome. J. Biol. Chem. 278, 25009-25013.

Woltjer, R.L., Nghiem, W., Maezawa, I., Milatovic, D., Vaisar, T., Montine, K.S., Montine, T.J., 2005. Role of glutathione in intracellular amyloid-a precursor protein/ carboxy-terminal fragment aggregation and associated cytotoxicity. J. Neurochem. 93, 1047-1056.

Yan, J.J., Cho, J.Y., Kim, H.S., Kim, K.L., Jung, J.S., Huh, S.O., Suh, H.W., Kim, Y.H., Song, D.K., 2001. Protection against $\beta$-amyloid peptide toxicity in vivo with long-term administration of ferulic acid. Br. J. pharmacol. 133, 89-96.

Yang, D.S., Kumar, A., Peterson, J., Peterhoff, C.M., Duff, K., Nixon, R.A., Jeyathevan, R., Martins, R.N., Cataldo, A.M., 2004. Neurodegeneration in a mouse model of Alzheimer's disease (AD): roles of apoptosis and autophagy. Neurobiol. Aging 25, S437.

Yankner, B.A., 1996. Mechanisms of neuronal degeneration in Alzheimer's disease. Neuron 16, 921-932.

Yogeeta, S.K., Raghavendran, H.R.B., Gnanapragasam, A., Subhashini, R., Devaki, T., 2006. Ferulic acid with ascorbic acid synergistically extenuates the mitochondrial dysfunction during $\beta$-adrenergic catecholamine induced cardiotoxicity in rats. Chem. Biol. Inter. 163 (1-2), 160-169. 
Yu, L., Wan, F., Dutta, S., Welsh, S., Liu, Z., Freundt, E., Baehrecke, E.H., Lenardo, M., 2006. Autophagic programmed cell death by selective catalase degradation. Proc. Natl. Acad. Sci. USA 103, 4952-4957.
Zhu, X., Raina, A.K., Lee, H.G., Chao, M., Nunomura, A., Tabaton, M., Petersen, R.B., Perry, G., Smith, M.A., 2003. Oxidative stress and neuronal adaptation in Alzheimer disease: the role of SAPK pathways. Antioxid. Redox Signal. 5, 503-506. 